
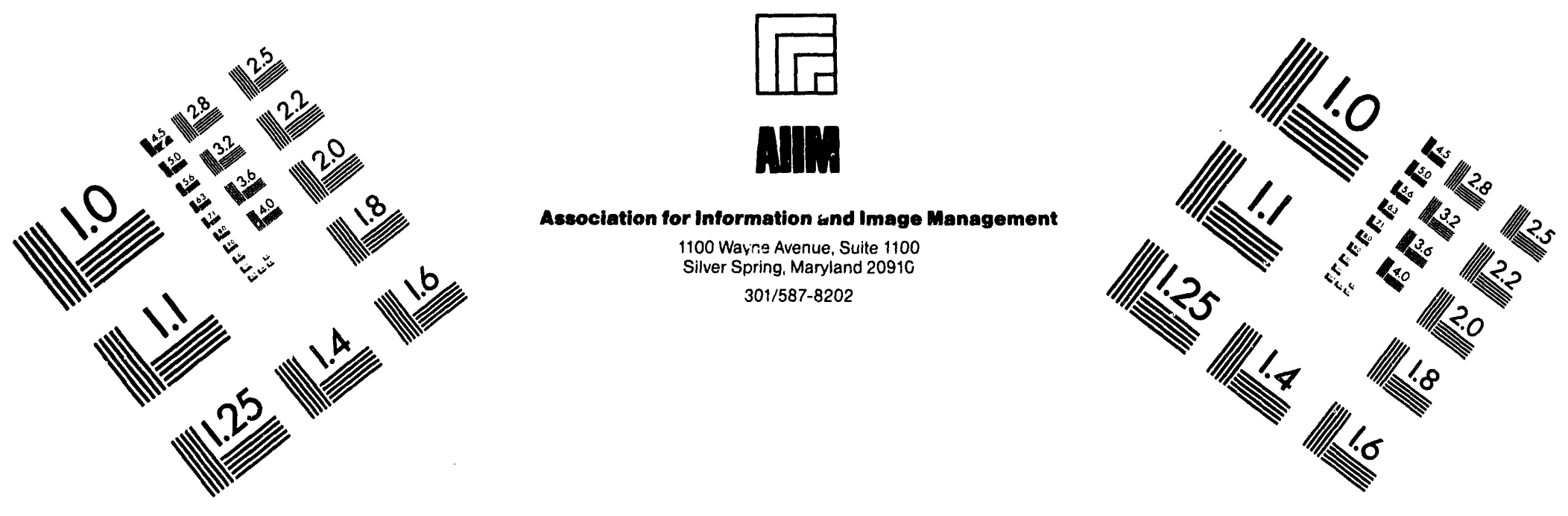

\title{
Centimeter
}

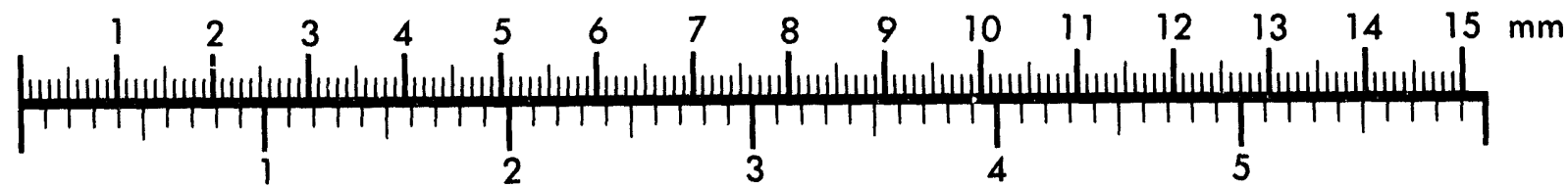

Inches
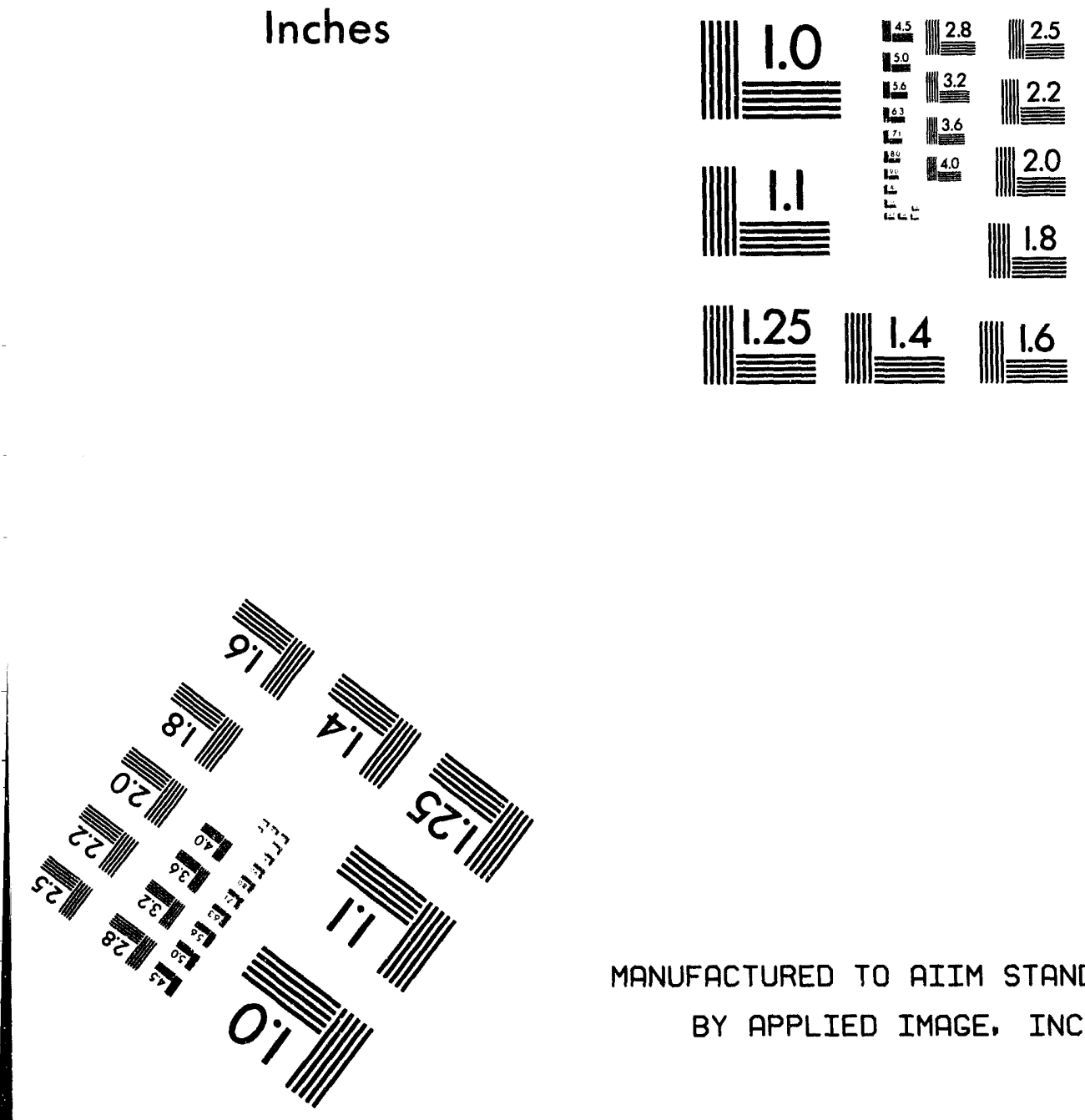

MANUFACTURED TO AIIM STANDARDS

BY APPLIED IMAGE, INC.

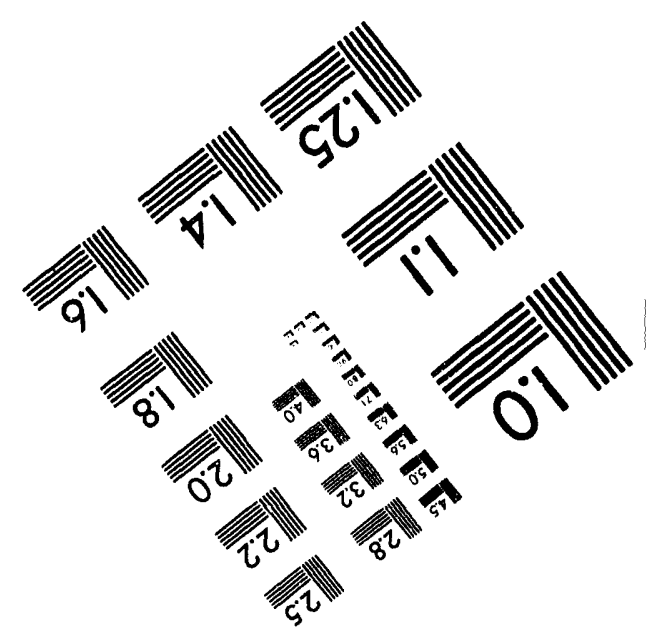



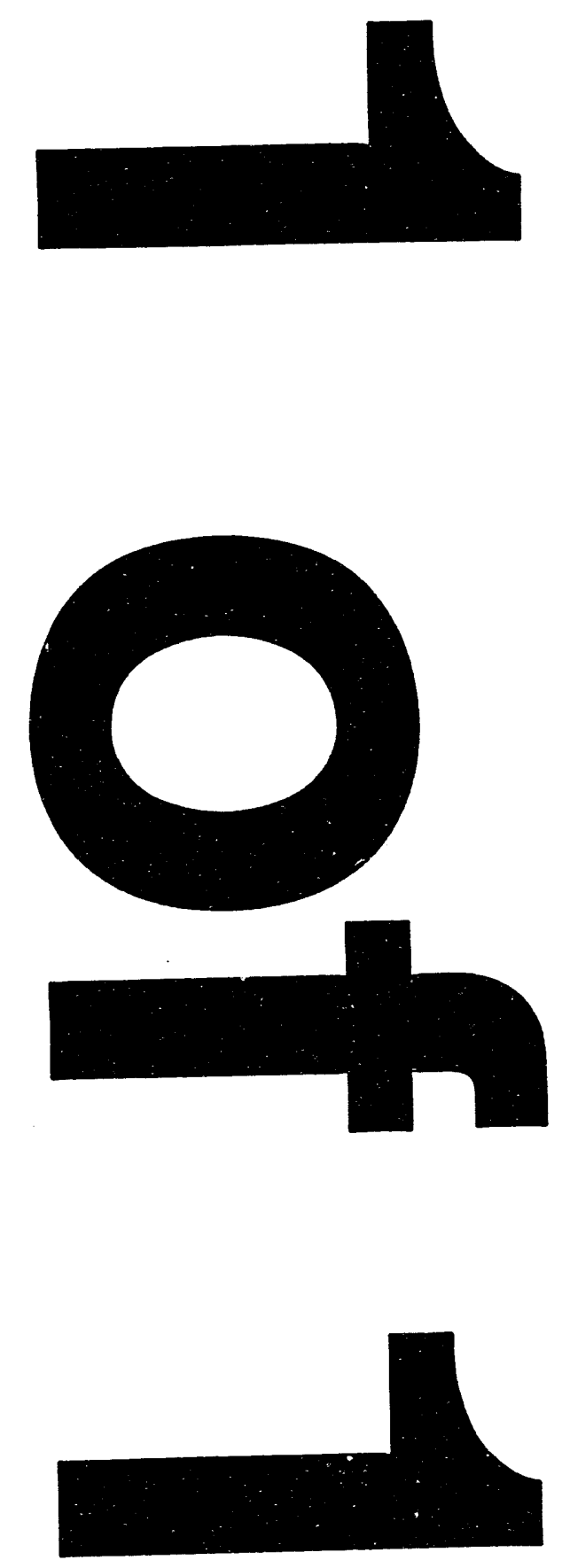


\title{
SAND 94-1489C
}

\section{ATTRITION AND CARBON FORMATION ON IRON CATALYSTS}

\author{
Steven D. Kohler, Mark S. Harrington, and Nancy B. Jackson \\ Sandia National Laboratories \\ P.O. Box 5800, MS 0790 \\ Albuquerque, NM, 87185-0790 \\ and \\ Mehul Shroff, Dinesh S. Kalakkad and Abhaya K. Datye \\ Department of Chemical and Nuclear Engineering \\ University of New Mexico \\ Albuquerque, NM, 87131
}

KEYWORDS: Attrition, carbon deposition, slurry bubble column

\begin{abstract}
A serious engineering problem that needs to be addressed in the scale-up of slurry-phase, Fischer-Tropsch reactors is attrition of the presipitated iron catalyst. Attrition, which can break down the catalyst into particles too small to filter, results from both mechanical and chemical forces. This study examines the chemical causes of attrition in iron catalysts. A bench-scale, slurry-phase CSTR is used to simulate operating conditions that lead to attrition of the catalyst. The average particle size and size distribution of the catalyst samples are used to determine the effect of slurry temperature, reducing gas, gas flow rate and time upon attrition of the catalyst. Carbon deposition, a possible contributing factor to attrition, has been examined using gravimetric analysis and TEM. Conditions affecting the rate of carbon deposition have been compared to those leading to attrition of the precipitated iron catalyst.
\end{abstract}

\section{INTRODUCTION}

In the investigation of the use of slurry-phase bubble columns for exothermic synthesis gas reactions, including Fischer-Tropsch synthesis and methanol synthesis, one of the biggest challenges presented by the process is development of the catalyst. In the typical Fischer-Tropsch use of the bubble column, the catalyst is suspended in a wax and synthesis gas is bubbled up through the column. Since the Fischer-Tropsch process produces wax, the wax must be continuously extracted from the column and the catalyst must be separated from the wax for sake of purity and to keep the catalyst concentration constant within the reactor. Therefore, the catalyst must be large enough to be filtered easily from the wax, but as small as feasibly possible to enhance activity. Catalyst attrition is a major problem at low $\mathrm{H}_{2} / \mathrm{CO}$ ratios with carbon deposition proposed as the contributing factor to chemical attrition of the catalyst.

\section{EXPERIMENTAL}

The catalyst used in this study was a precipitated and spray-dried, proprietary iron catalyst made by United Catalyst Inc. for the U.S. Department of Energy. The catalyst consisted 
of iron oxide and copper oxide in a ratio of about 9:1. Trace amounts of potassium oxide were also present. Transmission electron microscopy (TEM) and scanning electron microscopy (SEM) of the untreated catalyst particles showed that the samples were about 20-50 $\mu \mathrm{m}$ in diameter with a significant amount of micron and submicron fines. The larger particles were made up of angular, faceted, single-crystal grains (1-2 $\mu \mathrm{m})$ with similar orientation that were agglomerated together. See Figure 1. The particle size of three similarly prepared Fischer-Tropsch catalysts were measured using a sedimentationtype particle size analyzer. Particle size analysis confirmed the existence of large amounts of micron and submicron fine particles. Particle size measurements are listed in Table 1.

This transmission electron microscopy was performed on a $200 \mathrm{kV}$ JEOL JEM 2000FX rnicroscope and the scanning electron microscopy utilized a Hitachi S800 microscope. Thermal gravimetric analysis (TGA) was performed using a Dupont 951 Thermalgravimetric Analyzer.

Carbon deposition was studied during pretreatment and during Fischer-Tropsch synthesis by TGA and TEM. The catalysts were pretreated in the TGA or in a microreactor for TEM work with $\mathrm{H}_{2}$ or $\mathrm{CO}$ at $270^{\circ} \mathrm{C}$ and then reacted in $\mathrm{H}_{2} / \mathrm{CO}(0.7: 1)$ at $250^{\circ} \mathrm{C}, 275^{\circ} \mathrm{C}$, and $300^{\circ} \mathrm{C}$. The catalysts were pretreated for $10-14 \mathrm{hrs}$ and reacted for $10-14 \mathrm{hrs}$ in the TGA. In the microreactor for TEM studies, the catalysts were pretreated for $3 \mathrm{hrs}$ and reacted for $3 \mathrm{hrs}$.

\section{RESULTS}

Analysis in TEM showed that activation in carbon monoxide before reaction in synthesis gas deposited more carbon on the surface of the catalyst than activation in hydrogen before reaction. The deposited carbon was amorphous in structure. All catalysts, regardless of pretreatment, appeared to have both carbide and oxide phases present after reaction. As the temperature of the synthesis gas reaction is increased, the thickness of the carbon deposited on the iron oxide catalyst also increased. Pretreatment in $\mathrm{CO}$ followed by synthesis gas at $300^{\circ} \mathrm{C}$ showed the thickest layer of amorphous carbon. The individual grains showed signs of separation; the agglomerate was breaking up. The diffraction pattern showed a greatly diminished oxide phase while the pattern of the carbide phase suggested randomly oriented grains with loss of orientation relative to the original crystal. This breakup was also seen in catalysts pretreated in hydrogen and followed by synthesis gas at $300^{\circ} \mathrm{C}$. It also appears from TEM that there is a breakdown of the parent agglomerate template at synthesis temperature greater than $275^{\circ} \mathrm{C}$ which causes separation of the catalyst into individual crystallites (1-2 $\mu \mathrm{m}$ in size) which leads to attrition over time. At synthesis temperatures below $275^{\circ} \mathrm{C}$, oxidation of the iron catalyst showed a return of the original microstructure of the catalyst. Oxidation immediately following pretreatment of the catalyst in either $\mathrm{H}_{2}$ or $\mathrm{CO}$ caused a return to the original microstructure.

TGA results confirm the increase in the amount of amorphous carbon during pretreatment in carbon monoxide and at higher synthesis reaction temperatures. In addition, TGA 
results indicate that the breakdown of the catalyst due to carbon deposition can occur at temperatures lower than $275^{\circ} \mathrm{C}$, but at reaction times longer than those analyzed using TEM. TGA results show that regardless of the temperature of reaction or pretreatment gas, as the reaction in synthesis gas proceeds, the catalyst continues to gain weight at a rate proportional to the temperature. This continued weight gain implies continued carbon deposition leading to an eventual breakdown of the catalyst agglomerate into individual particles. The weight gain of the samples in the TGA due to synthesis reaction is shown in Table 2.

\section{CONCLUSIONS}

1. TEM analyses show that at reaction temperatures above $275^{\circ} \mathrm{C}$ there is significant carbon deposition and a breakdown of the parent iron catalyst agglomerate which causes the particles to disintegrate into individual crystallites (1-2 $\mu \mathrm{m}$ in size), a phenomena which would lead to attrition.

2. Pretreatment in $\mathrm{CO}$ followed by synthesis gas at $300^{\circ} \mathrm{C}$ showed the thickest layer of amorphous carbon in TEM.

3. The amount of carbon deposited increased with increasing temperature. The deposition rate was proportional to temperature.

4. TGA results show that weight gain continues at reaction temperatures below $275^{\circ} \mathrm{C}$. The continued weight gain implies continued carbon deposition which could lead to eventual breakdown of the agglomerate into individual crystallites.

5. The diffraction pattern of the catalyst after reaction showed both a carbide and oxide phase. The diffraction pattern did not depend upon the pretreatment gas used.

\section{ACKNOWLEDGMENTS}

This work performed at Sandia National Laboratories, which is funded by the U.S. Department of Energy under contract DE-AC04-94AL85000, and at the University of New Mexico.

\section{DISCLAIMER}

\footnotetext{
This report was prepared as an account of work sponsored by an agency of the United States Government. Neither the United States Government nor any agency thereof, nor any of their employees, makes any warranty, express or implied, or assumes any legal liability or responsibility for the accuracy, completeness, or usefulness of any information, apparatus, product, or process disclosed, or represents that its use would not infringe privately owned rights. Reference herein to any specific commercial product, process, or service by trade name, trademark, manufacturer, or otherwise does not necessarily constitute or imply its endorsement, recommendation, or favoring by the United States Government or any agency thereof. The views and opinions of authors expressed herein do not necessarily state or reflect those of the United States Government or any agency thereof.
} 


\begin{tabular}{|c|c|c|c|c|}
\hline SAMPLE & $\begin{array}{c}\text { NUMBER } \\
\text { DISTRIBUTION } \\
\text { MEDIAN } \\
\text { DIAMETER } \\
\end{array}$ & $\begin{array}{c}\text { NUMBER } \\
\text { DISTRIBUTION } \\
\text { MODAL } \\
\text { DIAMETER } \\
\end{array}$ & $\begin{array}{c}\text { MASS } \\
\text { DISTRIBUTION } \\
\text { MEDIAN } \\
\text { DIAMETER } \\
\end{array}$ & $\begin{array}{c}\text { MASS } \\
\text { DISTRIBUTION } \\
\text { MODAL } \\
\text { DIAMETER } \\
\end{array}$ \\
\hline $\begin{array}{c}\text { CATALYST } \\
\text { A } \\
\end{array}$ & $0.37 \mu \mathrm{m}$ & $0.31 \mu \mathrm{m}$ & $7.97 \mu \mathrm{m}$ & $28.85 \mu \mathrm{m}$ \\
\hline $\begin{array}{c}\text { CATALYST } \\
\text { B } \\
\end{array}$ & $0.32 \mu \mathrm{m}$ & $0.20 \mu \mathrm{m}$ & $22.22 \mu \mathrm{m}$ & $30.93 \mu \mathrm{m}$ \\
\hline $\begin{array}{c}\text { CATALYST } \\
\text { C }\end{array}$ & $\begin{array}{c}\text { NOT } \\
\text { AVAILABLE }\end{array}$ & $10.0 \mu \mathrm{m}$ & $10.24 \mu \mathrm{m}$ & $21.94 \mu \mathrm{m}$ \\
\hline
\end{tabular}

Table 1 - Particle size analysis of iron oxide catalysts

\begin{tabular}{|c|c|c|c|}
\hline $\begin{array}{c}\text { PRETREATMENT } \\
\text { GAS }\end{array}$ & $\begin{array}{c}\text { PRETREATMENT } \\
\text { TEMPERATURE } \\
250^{\circ} \mathrm{C}\end{array}$ & $\begin{array}{c}\text { PRETREATMENT } \\
\text { TEMPERATURE } \\
275^{\circ} \mathrm{C}\end{array}$ & $\begin{array}{c}\text { PRETREATMENT } \\
\text { TEMPERATURE } \\
300^{\circ} \mathrm{C}\end{array}$ \\
\hline HYDROGEN & $\mathbf{0 . 0 4 5} \mathbf{~ m g} / \mathbf{h r}$ & $\mathbf{0 . 0 8 3} \mathbf{~ m g} / \mathbf{h r}$ & $\mathbf{0 . 1 1} \mathbf{~ m g / h r}$ \\
\hline $\begin{array}{c}\text { CARBON } \\
\text { MONOXIDE }\end{array}$ & $\mathbf{0 . 2 2} \mathbf{~ m g / h r}$ & $\mathbf{0 . 6 8} \mathbf{~ m g} / \mathbf{h r}$ & $\mathbf{1 . 8 4} \mathbf{~ m g / h r}$ \\
\hline
\end{tabular}

Table 2 - Rate of catalyst weight gain during reaction in synthesis gas at $270^{\circ} \mathrm{C}$. Weight gain was measured by thermal gravimetric analysis after pretreatment in either hydrogen or carbon monoxide at $250^{\circ} \mathrm{C}, 275^{\circ} \mathrm{C}$, or $300^{\circ} \mathrm{C}$. 


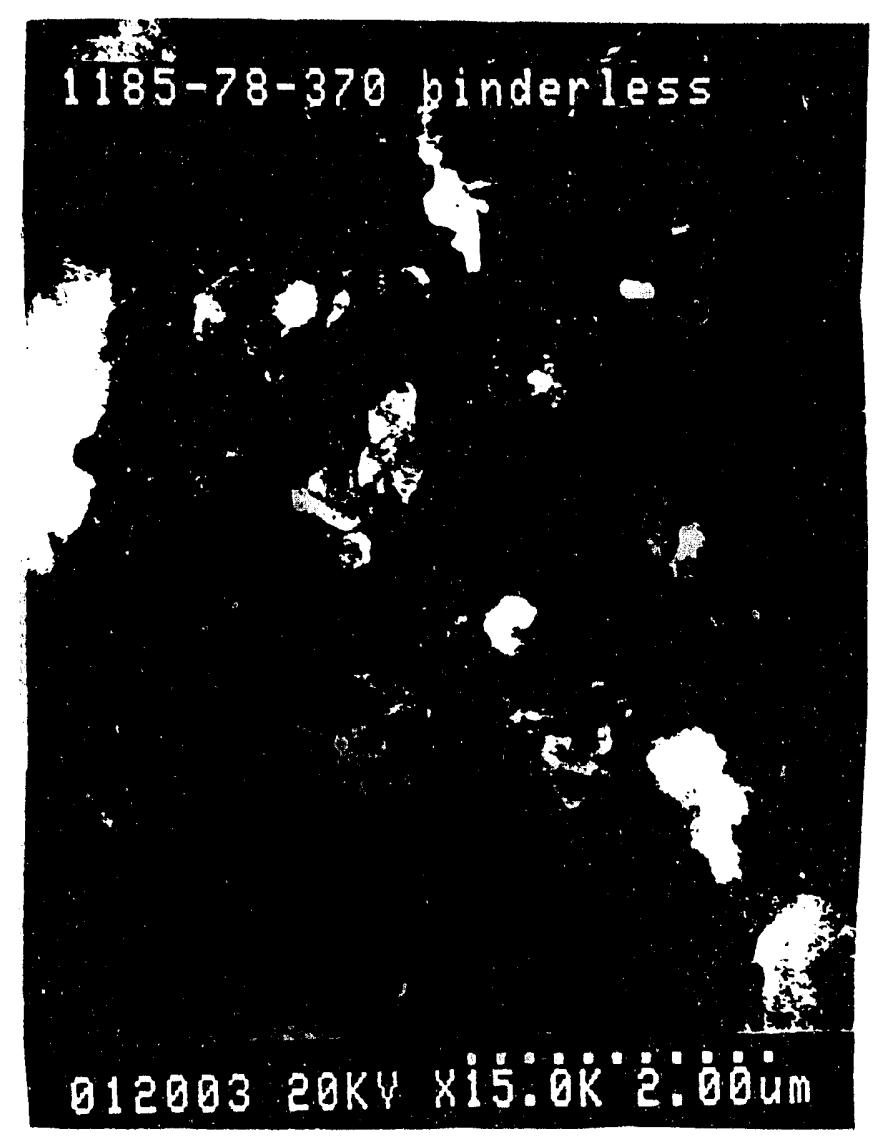

Figure 1 - SEM shows that the surface of the iron catalyst consists of agglomerated smaller, angular crystallites, which are particularly susceptible to attrition. 

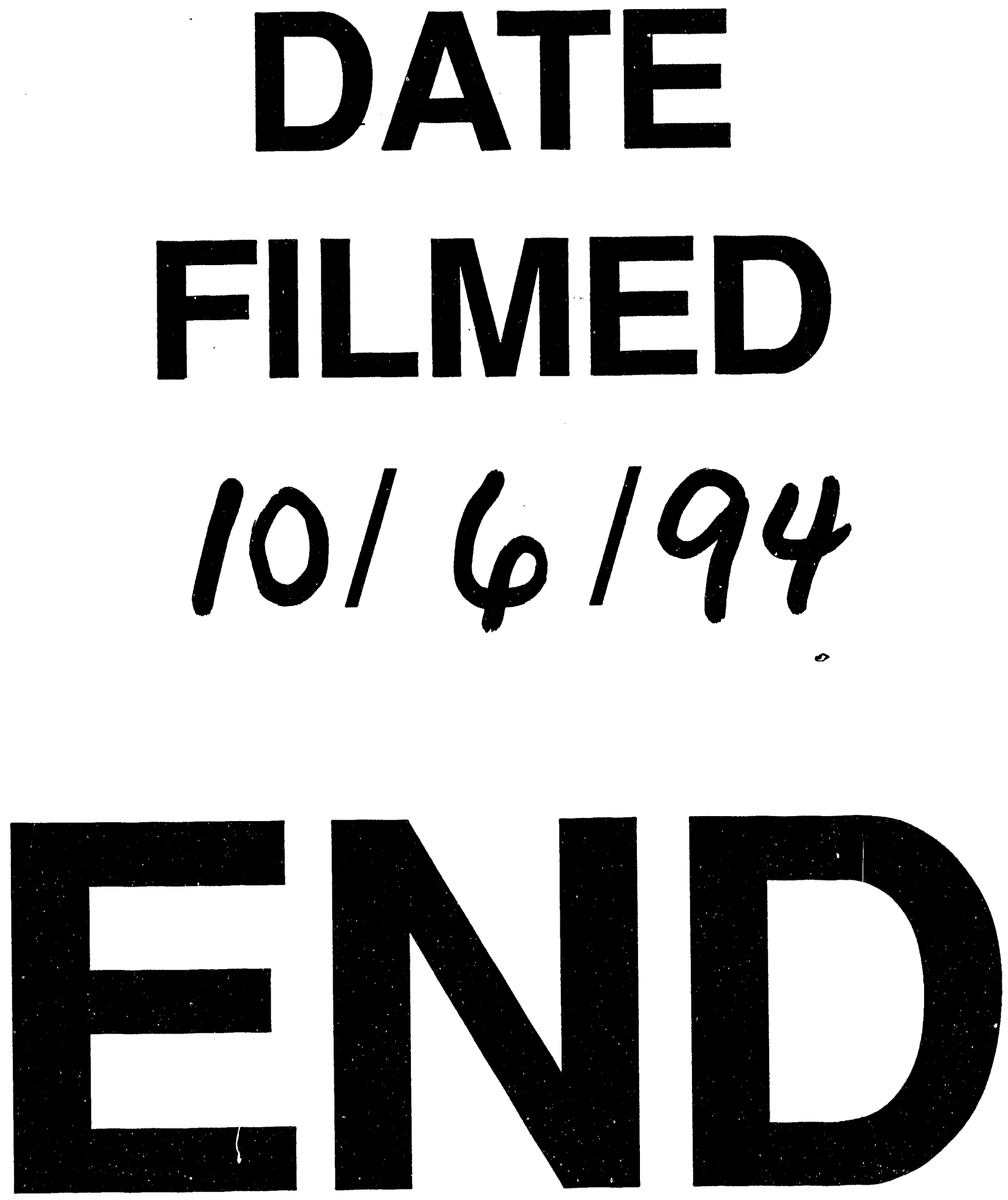


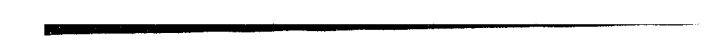

